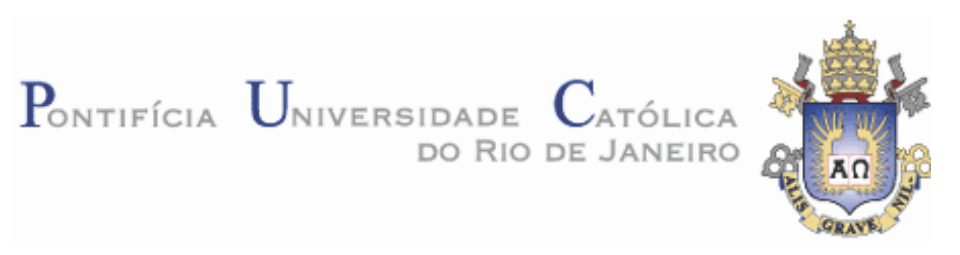

André de Barros Borges

CONSIDERAÇÕES SOBRE DERRIDA E A UNIVERSIDADE

Tese apresentada como requisito parcial para a obtenção do título de Doutor pelo Programa de Pós-Graduação em Filosofia do Departamento de Filosofia do Centro de Teologia e Ciências Humanas da PUC-Rio.

Orientador: Paulo Cesar Duque-Estrada

Rio de Janeiro, março de 2010 


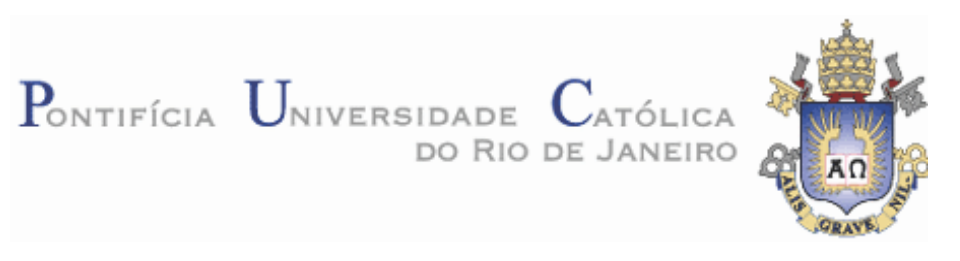

André de Barros Borges

\title{
Considerações sobre Derrida e a Universidade
}

Tese apresentada como requisito parcial para a obtenção do título de Doutor pelo Programa de Pós-Graduação em Filosofia do Departamento de Filosofia do Centro de Teologia e Ciências Humanas da PUC-Rio. Aprovada pela Comissão Examinadora abaixo assinada.

\author{
Prof. Paulo Cesar Duque-Estrada \\ Orientador \\ Departamento de Filosofia - PUC-Rio
}

Prof. Andrea Bieri

Departamento de Filosofia - PUC-Rio

Prof. Rafael Haddock-Lobo

Universidade Federal do Rio de Janeiro - UFRJ

Prof. Maurício Albuquerque Rocha

Universidade Estadual do Rio de Janeiro - UERJ

Prof. Leonardo Maia Bastos Machado Universidade Estadual do Sudoeste da Bahia - UESB

Prof. Paulo Fernando Carneiro de Andrade Coordenação Setorial do Centro de Teologia e Ciências Humanas - PUC-Rio

Rio de Janeiro, 15 de março de 2010 
Todos os direitos reservados. É proibida a reprodução total ou parcial do trabalho sem autorização da universidade, do autor e do orientador.

\section{André de Barros Borges}

Graduou-se em Filosofia pela Universidade Federal de Goiás (UFG), em 2000. Graduou-se em Direito pela Pontifícia Universidade Católica de Goiás (PUC-Goiás), em 2000. É mestre em Filosofia pela Pontifícia Universidade Católica do Rio de Janeiro (2004). Em 2005, ingressou no Doutorado em Filosofia da PUC-Rio, concluído em março de 2010, com a apresentação desta tese. É membro do Núcleo de Estudos em Ética e Desconstrução (Need-PUCRio).

Borges, André de Barros

Considerações sobre derrida e a universidade / André Borges ; orientador: Paulo Cesar Duque Estrada. - 2010.

162 f. ; $30 \mathrm{~cm}$

Tese (doutorado)-Pontifícia Universidade Católica do Rio de Janeiro, Departamento de Filosofia, 2010. Inclui bibliografia

1. Filosofia - Teses. 2. Universidade. 3. Desconstrução. 4. Ensino. I. Duque-Estrada, Paulo César. II. Pontifícia Universidade Católica do Rio de Janeiro. Departamento de Filosofia. III. Título.

CDD: 100 


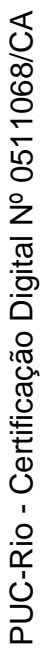

Para meus pais, Paulo Cezar e Terezinha. 


\section{Agradecimentos}

Agradeço ao Conselho Nacional de Pesquisa (CNPq), pelo apoio financeiro sem o qual não teria sido possível realizar esta pesquisa.

Agradeço ao orientador deste trabalho, professor Paulo Cesar DuqueEstrada, pela paciência e amizade.

Também agradeço à professora Suzanne Steinberg, pelas importantes sugestões e pela acolhida na Brown University.

Agradeço à Coordenação Central de Cooperação Internacional (CCCI) da Pontifícia Universidade Católica do Rio de Janeiro (PUC- Rio), pelo empenho para que o meu estágio de doutorado fosse realizado nos Estados Unidos.

Agradeço também aos professores e funcionários do Departamento de Filosofia da PUC-Rio e aos funcionários da biblioteca, pela atenção com que sempre fui atendido.

Agradeço à Luanda, pelas importantes conversas e sugestões.

Por fim, agradeço à Pontifícia Universidade Católica do Rio de Janeiro (PUC- Rio), pelos seis anos em que permaneci nessa instituição, fazendo o mestrado e o doutorado, onde tive a oportunidade de assistir a cursos memoráveis, com grandes mestres, que marcaram para sempre meu percurso filo sófico. 


\section{Resumo}

Borges, André de Barros; Duque Estrada, Paulo Cesar. Considerações sobre Derrida e a Universidade. Rio de Janeiro, 2010. 162 p. Tese de Doutorado - Departamento de Filosofia, Pontifícia Universidade Católica do Rio de Janeiro.

A hipótese interpretativa que utilizamos nesta tese de doutorado é a de que a compreensão que Derrida tem da ideia de "contra" é fundamental para compreendermos seu pensamento sobre a Universidade e sua relação com a filosofia. A análise caminha na direção de que o pensamento derridiano sobre a questão universitária é um desdobramento da "ética da aporia", que, para nós, é marcante em seu desenvolvimento intelectual. No primeiro capítulo, tratamos sobre a relação entre as ideias "contra-instituição" e "desconstrução". No segundo capítulo, focamos a relação entre desconstrução e ensino. No terceiro capítulo, mostramos como Derrida desenvolve certa fidelidade à ideia de Universidade, fidelidade distante da significação comum, pois essa fidelidade opera com a lógica do "com-contra". E no quarto capítulo, mostramos a Universidade contemporânea a partir de uma ótica desconstrucionista. A pesquisa se baseou nos escritos de Derrida sobre a Universidade, a disciplina Filosofia e a Faculdade de Filosofia, reunidos no famoso livro Du Droit a La Philosophie. Como o próprio filósofo pontua - em alguns textos que veremos ao longo desta tese de doutorado - , o "contra", a "oposição", insinua um movimento "com-contra", um torneamento "acerca de" e "longe de", uma medida de distância e de proximidade. Ao retirar os termos "contra" ou "oposição" de sua significação comum, compreendemos um movimento contrainstitucional, mais especificamente contra as Universidades. Chamaremos a instituição imaginada por Derrida de “contrainstituição". Tal aspecto contrainstitucional pode também ser visto como componente da "ética da aporia", de que tratamos na conclusão do trabalho.

\section{Palavras-chave}

Universidade; desconstrução; filosofia; ensino. 


\section{Abstract}

Borges, André de Barros; Duque-Estrada, Paulo Cesar (Advisor). Considerations about Derrida and University. Rio de Janeiro, 2010. 162 p. Doctoral Thesis - Departamento de Filosofia, Pontifícia Universidade Católica do Rio de Janeiro.

The hypothesis used in this doctoral thesis is that the understanding of Derrida's notion of "counter" is fundamental to understanding Derrida's thoughts concerning the university and its relation to philosophy. The analysis asserts that the thought of Derrida on the University is an offshoot of "ethics of aporia" which for us is remarkable in Derrida's intellectual development. In the first chapter we address the relationship between ideas "counter-institution" and "deconstruction". In the second chapter we focus on the relationship between deconstruction and teaching. The third chapter will show how Derrida develops the idea of lo yalt y to the University. This definition of Fidelity is far from ordinary, because this loyalty operates in the logic of "with-against". In the fourth chapter we deal with the deconstructivist aspect of contemporary University. Our research is based on the writings of Derrida on the University, discipline philosophy and the Faculty of Philosophy, meeting in the famous book Du Droit a La Philosophie. As Derrida himself points out in some texts that we will encounter throughout this work, the "counter", the "opposition" implies a movement "with-against", a turning around and away from, a measure of distance and proximity. When Derrida drops the term "counter or opposed" of the ordinary meaning of term, we understand this to be a movement against the institutional-Derrida in relation to institutions and more specifically to the institution of the University. We call the institution imagined by Derrida the "counter-institution." This aspect of the counter-institution can also be viewed as a component of the "ethics of aporia" developed by Derrida. We address this in the conclusion of thesis.

\section{Keywords}

University; deconstruction; philosophy; teaching. 


\section{Sumário}

1. Introdução 10

1.1. Contraintrodução 30

1.2. O Sonho do Outro 34

1.3. O Contrato Assimétrico 35

1.4. Uma Palavra sobre a Palavra "Contra" 36

2. Contrainstituição, Contradesconstrução 39

2.1. Contrainstituição, Contradesconstrução 39

2.2. Contratemporalidade 42

2.3. Contradefinições 49

3. Ensinando a Desconstrução 55

3.1. Universidade e Cultura 55

3.2. Ensino, Cultura e Dádiva 60

3.3. Ensino e Desconstrução 67

3.4. Desconstrução e Liberdade Acadêmica 69

3.5. A Monstruosidade e o Performativo 74

4. A Fidelidade de um Guardião $\quad 80$

4.1. Visões da Universidade: entre a barreira protetora e o 80

4.2. A Universidade sem Condição 89

4.3. Onde Começa e como Acaba um Corpo Docente 96

4.4. O Conflito das Faculdades 102

5. Revisando Derrida 112

5.1. Revisando Derrida 112

5.2. O Ouvido do Outro 119

5.3. "Se Houver Provas, não há Testemunho" 122

5.4. A Era da Auditoria 130 
6. Considerações Finais 134

6.1. A Universidade Moderna 134

6.2. A Questão da Herança 136

6.3. O Direito da Filosofia nas Instituições 138

6.4. O Aspecto Político: aporia do tempo e da lei 141

6.5. A Étia da Aporia 147

6.6. A Universidade Contemporânea: para aonde 152 vamos?

7. Referências Bibliográficas 